\title{
JESZCZE O HOTELU LAMBERT
}

RadosŁaw PaweŁ Żurawski vel Grajewski, Ognisko permanentnej insurekcji. Powstanie 1846 roku i likwidacja Rzeczypospolitej krakowskiej w , dyplomacji” Hotelu Lambert wobec mocarstw europejskich (18461847), Wydawnictwo Łódzkie, Kraków-Lódź 2018, ss. 488

Autor tego ambitnego i starannie udokumentowanego studium z dziejów europejskiej dyplomacji legitymuje się bogatym dorobkiem naukowym na temat działalności emigracyjnej Hotelu Lambert ${ }^{1}$. Książę Adam Jerzy Czartoryski nigdy nie był sympatykiem imperium napoleońskiego, ale po powstaniu 1830/1831 r., przebywając już na emigracji, zdumiewająco zgadzał się z myślą Napoleona wyrażoną na Wyspie Świętej Heleny: „Europa, a szczególnie Anglia, powinny przeciwstawić się zjednoczeniu Polski z Rosją... Jeżeli Aleksander osiągnie akceptację Polaków dla rosyjskiego rządu, wówczas uczyni ogromny krok naprzód w planach podboju Indii"2. Cały dyplomatyczny wysiłek i energia księcia Czartoryskiego skupiły się na ostrzeganiu Londynu przed imperialistycznymi ambicjami Rosji, montowaniu w miarę harmonijnej polityki Anglii i Francji wobec Mikołaja I oraz próbach obrony systemu prawnego ustanowionego w Królestwie Polskim traktatem wiedeńskim z $1815 \mathrm{r}^{3}$

Fundamentem źródłowym recenzowanego dzieła stała się obfita, bo licząca aż siedemnaście tomów korespondencja księcia Adama zgromadzona w krakowskim Archiwum Czartoryskich (w pierwszej kolejności korespondencja z lordem Henrym Palmerstonem), następnie rozliczne zasoby i druki Foreign Office oraz przechowywana tam korespondencja konsula brytyjskiego w Warszawie płk. Charlesa Williama du Plata czy posła brytyjskiego w Petersburgu lorda Johna Bloomfielda. Autor dotarł także do korespondencji rosyjskiego ambasadora w Londynie, Ernesta

1 R.P. Żurawski vel Grajewski, Działalność księcia Adama Jerzego Czartoryskiego w Wielkiej Brytanii (1831-1832), Warszawa 1999; tenże, Pojedynek za kulisami wielkiej dyplomacji: księżna Dorothea Liven wobec Polski i Polaków, Warszawa 2005; tenże, Powstanie krakowskie 1846 r. w relacjach dyplomatów brytyjskich, w: Rok 1846 w Krakowie i Galicji. Odniesienia, interpretacje, pamięć, red. K.K. Daszyk, T. Kargol, T. Szubert, Kraków 2016, s. 157-169.

2 NAPOlÉon, Pensées politiques et sociales, rassemblées et présentées par Adrien Dansette, Paris 1969, s. 356-357.

3 W. ZAJEwski, Gabinety europejskie wobec sprawy polskiej w XIX wieku, „Twórczość”, 3(1983), s. 114-115. 
Iwanowicza Brunnowa. Bardzo starannie zbadał zasoby źródłowe PAN w Krakowie oraz Biblioteki Polskiej w Paryżu. Dokładnie przestudiował też opublikowane przez Hansarda sprawozdania z debat parlamentu brytyjskiego i prześledził debaty parlamentarne we Francji (w tym archiwa konsulatu francuskiego w Warszawie z lat 1828-1851). Przeanalizowanie tak imponującej podstawy źródłowej możliwe było dzięki hojnym stypendiom naukowym kilku fundacji (m.in. Lanckorońskich i Brzękowskich), a także wsparciu własnej uczelni. Autor bardzo umiejętnie korzystał z licznych publikacji naukowych - zarówno tych autorów, których uznajemy już dziś za klasyków: Marcelego Handelsmana, Mariana Kukiela, Stefana Kieniewicza czy Jerzego Skowronka, jak i młodszego pokolenia historyków: Krzysztofa Markiewicza czy Janusza Pezdy, a nawet całkiem nieznanych jeszcze w Polsce badaczy, jak Miłosz K. Cybowski. Wykaz źródeł oraz literatury pamiętnikarskiej i naukowej (s. 431-446) robi na recenzencie wrażenie wyjątkowego maksymalizmu badawczego - wrażenie imponujące! Mamy tu już do czynienia z zupełnie inną sytuacją badacza niż w czasach PRL-u, gdy historyka wysyłanego przez PAN na bardzo nędzne stypendium kontrolowano nawet po powrocie, sprawdzając, jakie czasopisma czytał w Bibliotece Polskiej w Paryżu!

Recenzowana książka składa się z czterech rozdziałów, które przedstawiają stanowiska europejskich dyplomacji wobec Wolnego Miasta Krakowa w różnych latach. Pierwszy rozdział dotyczy sytuacji Krakowa do kwietnia 1846 r., gdy w stolicach Anglii i Francji „stało się oczywiste, iż insurekcja w Polsce ostatecznie upadła” (s. 12). Drugi relacjonuje europejską grę dyplomatyczną wobec przyszłości Krakowa jako wolnego miasta. Trzeci omawia reakcje mocarstw na wcielenie Krakowa do monarchii habsburskiej (do stycznia 1847 r.). Czwarty zaś prezentuje europejską kampanię dyplomatycznego sprzeciwu Hotelu Lambert wobec arbitralnych decyzji Austrii.

Wiadomo, że 21 lutego 1846 r. z inicjatywy Towarzystwa Demokratycznego Polskiego wybuchło w Wolnym Mieście Krakowie trójzaborowe powstanie zbrojne. 22 lutego w oswobodzonym Krakowie ukonstytuował się Rząd Narodowy Rzeczypospolitej Polskiej, na czele którego pierwotnie miał stanąć filozof Karol Libelt, a wodzem naczelnym miał zostać gen. Ludwik Mierosławski. Akces do powstania narodowego zgłosiło także Towarzystwo Insurekcyjno-Monarchiczne, a zaskoczony wydarzeniami w Krakowie książę Adam Czartoryski zaakceptował go, przekonany argumentacją płk. płk. Władysława Zamoyskiego i Feliksa Breańskiego. Tymczasem 24 lutego 1846 r. w miejsce aresztowanego przez Prusaków Mierosławskiego dyktatorem powstania ogłosił się Jan Tyssowski. Dwa dni później dowodzeni przez płk. Adama Suchorzewskiego powstańcy zostali rozbici przez ppłk. Ludwiga von Benedeka, a schwytanych polskich jeńców wymordowali zbunto- 
wani chłopi. 4 marca 1846 r. dyktator Tyssowski ogłosił kapitulację, po czym do Krakowa wkroczyły oddziały austriackie, a kanclerz Klemens von Metternich przekonywał całą Europę, że „podjął ten krok dla ochrony spokojnych mieszkańców” (s. 37). Co więcej, stwierdził, że rewolucję wywołali polscy emigranci z Paryża, a głoszony przez nich ,polonizm to tylko etykieta, za którą czai się najbardziej brutalna forma rewolucji, ta rewolucja [zaś] opowiada się za obaleniem fundamentów, na których oparte jest społeczeństwo"4. W odpowiedzi na oszczerstwa Metternicha książę Czartoryski i jego angielscy sojusznicy - lord Cutts Stuart Dudley i szkocki radykał w Izbie Gmin Joseph Hume - podjęli w brytyjskim parlamencie ofiarną kampanię za utrzymaniem Wolnego Miasta Krakowa bez żadnych obcych garnizonów, zgodnie z zapisami traktatu wiedeńskiego z 1815 r. Księciu chodziło głównie o „potępienie ze strony Anglii i Francji postępowania Austrii w Galicji oraz poczynań wszystkich zaborców w Krakowie" (s. 414-415). Cała dobrze przemyślana strategia Czartoryskiego oraz jego angielskich i francuskich sprzymierzeńców zmierzała do tego, by rządy tych krajów nie tylko potępiły poczynania Austrii i Rosji w Krakowie, ale też ustanowiły w tym mieście swoje odrębne konsulaty. Najważniejsi politycy w Wiedniu bali się według autora, by Kraków „nie stał się miastem rosyjskim" (s. 425). Nie było to pozbawione podstaw, albowiem lord Palmerston konstatował w Londynie z depeszy brytyjskiego dyplomaty Williama du Plata, że „cała Galicja z ochotą rzuciłaby się w ramiona Rosji, bo ona gwarantowałaby bezpieczeństwo życia i majątku" (s. 161, przyp. 310). Choć Anglia i Francja nie były zachwycone wkroczeniem wojsk austriackich do Krakowa, to jednak wykluczały podejmowanie przeciwko Austrii jakiejkolwiek reakcji siłowej w jego obronie. Kontrakcja księcia Czartoryskiego nie mogła być skuteczna, ponieważ Paryż i Londyn bardzo mocno różniło podejście do sprawy tureckiej. W latach 1839-1841 spór sułtana Mahmuda z egipskim wicekrólem Muhammadem Alim nabrał cech militarnych. Anglia żywiła uzasadnione obawy, że popierająca ambitnego paszę Egiptu Francja już od 1798 r. zamierzała usadowić się nad Nilem, tak jak w 1830 r. uczyniła to w Algierii. Co prawda do starcia zbrojnego Francji z Anglią nie doszło, ponieważ Ludwik Filip zdymisjonował zbyt wojowniczego premiera Adolphe'a Thiersa, zastępując go kompromisowym François Guizotem, ale na konflikcie tym skorzystała Rosja ${ }^{5}$, a Egipt ostatecznie przymuszono do kompromisu z sułtanem Turcji. W tych okolicznościach książę Czartoryski zdawał sobie sprawę, że pojednanie Anglii z Francją będzie zadaniem bardzo trudnym,

\footnotetext{
4 A. Zamoyski, Urojone widmo rewolucji. Tajne spiski i tlumienie ruchów wolnościowych 1789-1848, Kraków 2016, s. 606-607.

5 H. Seton-Watson, The Russian Empire 1801-1917, Oxford 1967, s. 302-303; W. ZaJEWski, Europa wobec powstania 1863, „Znad Wilii”, 1(2013), s. 10-11.
} 
jeżeli w ogóle możliwym do osiągnięcia (s. 415). Jak konkluduje autor recenzowanej książki: „Generalnie, choć niejednomyślnie, parlament brytyjski podobnie jak francuski potępiał zabór Krakowa, a rząd podzielał pogląd o pogwałceniu tym aktem traktatu wiedeńskiego [i] odmawiał prawa wyłączności decyzji w kwestii Wolnego Miasta Krakowa dworom północnym” (s. 419).

Recenzowana publikacja to bardzo dojrzała i wyjątkowo dobrze udokumentowana monografia o dyplomatycznych konfliktach europejskich związanych z ostateczną likwidacją Wolnego Miasta Krakowa przy milczącej aprobacie głównych sygnatariuszy traktatu wiedeńskiego z $1815 \mathrm{r}$.

\section{BIBLIOGRAFIA}

NAPOLÉON, Pensées politiques et sociales, rassemblées et présentées par Adrien Dansette, Paris 1969. Rok 1846 w Krakowie i Galicji. Odniesienia, interpretacje, pamięć, red. K.K. Daszyk, T. Kargol, T. Szubert, Kraków 2016.

Seton-Watson H., The Russian Empire 1801-1917, Oxford 1967.

ZAJEwski W., Europa wobec powstania 1863, „Znad Wilii”, 1(2013).

ZAJEWSKI W., Gabinety europejskie wobec sprawy polskiej w XIX wieku, „Twórczość”, 3(1983).

ZамоYsкi A., Urojone widmo rewolucji. Tajne spiski i tlumienie ruchów wolnościowych 1789-1848, Kraków 2016.

Żurawski vel Grajewski R.P., Działalność księcia Adama Jerzego Czartoryskiego w Wielkiej Brytanii (1831-1832), Warszawa 1999.

Żurawski vel Grajewski R.P., Pojedynek za kulisami wielkiej dyplomacji: księżna Dorothea Liven wobec Polski i Polaków, Warszawa 2005.

ŻURAWSKI VEL GRAJEWSKI R.P., Powstanie krakowskie $1846 r$. w relacjach dyplomatów brytyjskich, w: Rok 1846 w Krakowie i Galicji. Odniesienia, interpretacje, pamięć, red. K.K. Daszyk, T. Kargol, T. Szubert, Kraków 2016.

Władystaw Zajewski emerytowany profesor PAN 